\title{
Characteristics of macho-leadership and the role of democracy as destination or path. Observation from an Indian civil society perspective
}

\section{Challenges}

It is a tragic comedy when the settled, well established, entrenched and powerful feel aggrieved, wronged and threatened. That seems to be the flavor of our times. Hence, the majority Hindu population is sought to be painted as a community under threat from the religious minorities in India, white citizens can be galvanized to feel threatened by immigrants in the US or Europe. And, where fear is successfully instilled 'messiahs' such as Trump, Erdogan, Duterte and Modi cannot be far away. These omnipotent 'Santa Clowns' can promise everything to everyone. It is hardly funny to see people in a trance whereby - in people's eyes - Trump seems to be constructing his wall across the Mexico border (and making America safe again, great again!) while he's actually playing golf at Mar-a-Lago. And, one must hasten to add that people in their waking dream believe that Mexico is writing the cheques for the wall! India's Prime Minister is believed to be creating jobs because he's making bombastic speeches and $\mathrm{Mr}$ Duterte is stamping out drugs from his country while his police run around trigger-happy.

\section{Factors that create fertile atmosphere for macho leadership}

1. Satellite and service economy: Most '3rd World' economies despite being primary producers have become satellite economies dependent and manipulated by the powerful ' 1 st World' that dictate terms of engagement, and the citizens of both, the 1st and 3rd World economies are inconsequential cogs in a monstrous system that only wants consumers.

2. Pay \& Use: Only those with the means have the right and access to services. In the two-thirds world context we're talking about food, water, sanitation, health, education etc. The State seems to be in retreat as far as welfare is concerned, so the ground is fertile for an omnipotent leader who will solve the world's problems with the wave of a magic wand.

3. Universalisation of middle-class norms, lifestyle, aspirations and the selling of unrealisable dreams that serve as escape from reality.

4. Changing language, unchanging reality: Paying lip service to buzz words such as 'sustainable development', 'participation', 'human rights', 'justice', while those at the wrong end of the line live and experience a vastly different reality that is cruel and violent.
5. A clinical lack of sensitivity to the growing violence and iniquity that characterizes our society. What is worse is that the influential-powerful-vocal-opinion makers blame the victims and tragically the oppressed/victims come to believe, buy the line that they are themselves to blame, and that only a prophet, messiah will deliver them to the Promised Land.

6. People vs. people: Managing to pit one set of oppressed against another set of poor.

7. Demonisation: While the violence of the system is denied or ignored, any self-defense actions by the poor leads to them being demonized as being 'anti-national', 'anti-development', Maoists, terrorists etc.

8. Loss of innocence: Spawns militancy, creates conditions where people lose faith in nonviolence and start thinking that only machismo, violence and militancy work.

9. Medicine worse than the illness: The litany of unresolved basic and burning problems gives birth to that machoist leader who will take care of humanity's problems.

Among the first things that 'Prophet', 'deliverer' serves is a concoction distilled out of fear, rumors, fake news and whippedup-hatred, stirred by macho messiahs, propagated by a fawning and groveling media. That is the ideal recipe for a short term feel-good intoxication. 'Messiahs' then seek to maintain that intoxicated high in people's sentiment by provocative slogans, fanning 'nationalist' flames by discovering or inventing enemies, inciting lynch mobs, floating emotive symbols using $\mathrm{Na}$ tion or religion (e.g. national flag, the holy cow, temple, mosque), bombastic announcements and claims that nobody hears about a second time. For instance in India

1. There have been tens of cow-related (considered holy by Hindus) vigilante killings since 2014 . $^{1}$

2. University students have been sent to jail and charged with sedition for shouting 'anti-national' slogans. ${ }^{2}$

3. The Ram Temple in Ayodhya is a recurrent theme that India's right wing, Hindu party resorts to before every elections. ${ }^{3}$

4. Various Indian State Governments are on a Statue construction spree: The Sardar Patel statue in Gujarat is 182 metres tall ${ }^{4}$ and was built at a cost of at least Rs. 3500 crore (approx. \$ 500 million); the Shivaji statue in Mumbai will be 190 metre tall; the planned Ram statue in Uttar Pradesh will measure 212 meters. 
5. There is a plan to install a battle tank inside Jawaharlal Nehru University in Delhi to inculcate the spirit of nationalism among students. ${ }^{5}$

6. Prime Minister Modi, when he was Chief Minister of Gujarat claimed that a State Government Corporation had discovered 20 trillion cubic feet of gas ${ }^{6}$ and that Gujarat would be energy rich etc. The claim was never heard of again after he became Prime Minister of India!

7. There are big investment jamborees held every two years called Vibrant Gujarat summits claiming billions of \$ investment, no more that $10-11 \%$ really materialize.

\section{Characteristics of the Macho leader}

To understand these Indian 'developments' in a wider context, there are characteristics world wide of mainly male human being as macho leaders:

1. Promises all things to all people without the scrutiny of how conflicting promises will be reconciled,

2. talks an appealing, even provocative language that presses the right buttons; viz., nationalism - religion - army development - national interest,

3. runs with the hare and hunts with the hound - the Trumps, Erdogans, Dutertes and Modis pay lip-service to the poor but are products of a religious leader-politician-corporate nexus,

4. mastery of the art of 'giving the dog a bad name and killing him'.

5. no remorse for the toxic atmosphere they create, the 'enemy' they paint, the violence they foment, they create the justification for lynch-mobs,

6. monopolise, dominate and dictate the discourse and

7. the only silver lining is that they do tremendous damage to their own party and organization in the long run and are a threat to the ideology they themselves profess.

\section{Why? The role of democracy}

There are two Why-questions, have to asked: Why do politician-leaders get away with lies? Why can some people be fooled all the time? An attempt to answer these questions would require de-constructing some of the pillars of democracy.

1. Democracy is an excellent political system that seems to serve everybody's interest. To the common citizen it gives the illusion of free choice, participation and power. To the decision-makers and vested interests it gives real power without bad optics. Democracy, therefore, becomes one more product of the glamorous, globalized market to be consumed like any other imported electronic gadget that is addictive and highly expensive but seemingly made available to the consumer (who is delusionary king) under some buy-one-get-one-free scheme.

2. The Citizen is hardly a rational creature, for the most part. Therefore, citizen-opinion is formed less by reason, more by newspaper headlines, sensational news and juicy gossip of Sunday tabloid supplements. To that extent the modern citizen is literate-uneducated and apathetic. Therefore, finding and investing in a 'strong' leader is the citizens' need so that they can absolve themselves of all responsibility. The ambitious (politician) and apathetic (citizen) scratch each other's back, so to say.
3. Parties are considered the main vehicles representing public opinion, whilst the opposition party is supposed to be a corrective force, keeping the ruling party on its toes and presenting an alternative. Have opposition parties in any democracy around the world lived up to that expectation? In reality we see the spectacle of a ruling party and an 'aspiring' ruling party - mirror images of each other (as far as real substance is concerned) rather than alternatives! Secondly, parties by their very nature, kill people's participation, sense of duty and responsibility by masquerading as the ultimate advocates and articulators of public opinion. Thirdly, populist compulsions and the rough and tumble of electoral politics prevent them from taking a holistic view of issues. The most radical green and left-oriented parties have met with such fate in the recent past. Confrontation is accepted as the cornerstone of democracy.

4. Elections should theoretically throw up the best candidates. But are parties guided by values and principles and elections fought on issues? An issue can - at best - whip up a temporary frenzy. Can one vote in four or five years mean democracy? Elections legitimize the use of money power to sway voters to vote for the 'lesser evil'.

5. Parliament: the temple of modern day representative democracy functions more like a club of the elite, where representatives of masses are more an exception rather than the rule. It is the abode of competing flocks that put up the charade of debate and transparency. An elite club disconnected from people and insulated from reality is an inherently corrosive formula for democracy.

6. Rule of Law is only as good as the people who formulate and enforce it. It does not function in a vacuum. It is a product of the social-economic-political-cultural milieu of any society. In practice, laws are made for the benefit of the powerful, to be observed by ordinary citizens. Their interpretation is usually subjective. In reality affairs of the human race in the 21 st century ought to be governed by something more humane and nonviolent.

7. 'Vibrant' Media does not have an existence independent of money power. It often manufactures news rather than just reporting or analyzing it. The role of the media in the run up to the second Iraq war is a case in point. Even $\mathrm{Al}$ Jazeera, which won plaudits for its reportage during that war, seemed to have an agenda while reporting news of the Arab Spring. It could certainly not be applauded for unbiased reporting on the protests in Bahrain for instance. The $\mathrm{BBC}$ also did not do its reputation any great service in the run up to the war to discover 'weapons of mass destruction' in Iraq! A neo-liberal milieu can indeed be infectious!

Adversity often puts us face to face with the worst, but also with the best that is in human nature. The financial crisis in the US and some parts of Europe in 2008 triggered the Occupy Wall street protests. One incident in Tunisia seemed to trigger the Arab Spring that affected Tunisia, Egypt, Libya, Yemen, Syria. Those who observed the unfolding events minutely would also have sensed jitters in the Chinese establishment. 


\section{Perspectives: Dynamics of Change}

For protests to snowball into a sustained movement and sustainable change would need a convergence of factors.

1. Fermenting disaffection: The groundswell of discontent due to economic problems, joblessness etc. decidedly sways public sentiment and anger when people sense (rightly or wrongly) that somebody else is taking away what should belong to them. There is such a thing as the 100th monkey phenomenon. Religious institutions (natural uniting force?) and gatherings also seem to play an important role.

2. Trigger: It still takes a trigger such as the self-immolation of Mohamed Bouazizi in Tunisia, or the suppression of peaceful demonstrations for the release of children in Dera'a, Syria, to start a movement.

3. Suppression: Rulers intoxicated with power fail to see the unmistakable shift in wind and reflexively try to suppress as they would have done many times before. This often proves fatal, as it did in Tunisia, Egypt, Yemen and Syria

4. Building critical mass: When started off by a single trigger or by a small group - if it can tap into the groundswell of public sentiment - would soon bring together disparate groups forming a large, even if temporary, alliance. This is why we saw the coming together of leftists, Islamists, social media-youth et al. in Tunisia, Egypt and other places.

5. Switching sides: Some allies, collaborators or co-travellers of the old order switch sides as soon as they see a shift in the wind and that has a great psychological effect in bringing about its collapse; quite often many people have their hearts on one side and feet on the other, they also contribute to change.

6. Compromise: Making common cause with various different groups with multiple interests and focal points calls for a process of collective give-and-take, something that in reality determines the health of any movement; for this to work, there has to be as much back-room spadework as visible actions.

7. Perspective: The immediate problem is the problems on the surface - the trigger. That then needs to be put into larger perspective, and a deeper analysis that results in mobilizing support, bringing disparate groups together, and provides the conceptual and ideological basis for change needs to be presented.

8. Alternative vision: Any movement can get durable traction only if an alternative vision is presented; it is usually the role of a leader, philosopher, visionary - occasionally a single individual may have these attributes, but often one single individual may not have them all, which is where diversity in collectives helps.

\section{Notes}

1 (https://en.wikipedia.org/wiki/Cow_vigilante_violence_in_India_since_2014).

2 (https://en.wikipedia.org/wiki/JNU_sedition_row).

3 (https://www.indiatoday.in/india/story/as-ram-mandir-demand-shines-brightother-ayodhya-temples-fade-into-oblivion-1404173-2018-12-07)

4 (http://www.statueofunity.in/about-us)

5 (https://www.thehindu.com/opinion/op-ed/all-true-patriots-will-welcome-thearmy-tank-in-jnu/article19436047.ece)

6 (https://www.indiatoday.in/magazine/states/story/20050711-narendra-modiannounces-biggest-gas-discovery-in-krishna-godavari-basin-7874202005-07-11)

\section{Anand Mazgaonkar}

brought up in a family inspired by the ideas of Mohandas K. Gandhi and Vinoba Bhave (one of the closest disciples of Gandhi), is a senior activist and one of the National Convenors of the National Alliance for People's Movements in India. Based in Gujarat he has been working in the state for several decades on issues of environment and social justice. He is part of a collective called Paryavaran Suraksha Samiti apart from various progressive and socialist fora at the state and national level.

doi.org/10.31244/zep.2019.01.08 